\title{
Effects of Varieties and Nitrogen Fertilizer on Yield and Yield Components of Maize on Farmers Field in Mid Altitude Areas of Western Ethiopia
}

\author{
Tolera Abera, ${ }^{1}$ Tolessa Debele, ${ }^{2}$ and Dagne Wegary ${ }^{3}$ \\ ${ }^{1}$ Natural Resources Management Research Process, Ambo Agricultural Research Center, Ethiopian Institute of Agricultural Research, \\ P.O. Box 382, Ambo, West Showa, Oromia, Ethiopia \\ ${ }^{2}$ Support to Agricultural Research for Development of Strategic Crops in Africa (SARD-SC), ICARDA, c/o ILRI, P.O. Box 5689, \\ Addis Ababa, Ethiopia \\ ${ }^{3}$ International Maize and Wheat Improvement Centre (CIMMYT), Global Conservation Agriculture Program, P.O. Box 5689, \\ Addis Ababa, Ethiopia \\ Correspondence should be addressed to Tolera Abera; thawwii2014@gmail.com
}

Received 14 August 2017; Accepted 10 October 2017; Published 29 November 2017

Academic Editor: Cristina Patanè

Copyright (c) 2017 Tolera Abera et al. This is an open access article distributed under the Creative Commons Attribution License, which permits unrestricted use, distribution, and reproduction in any medium, provided the original work is properly cited.

\begin{abstract}
Yield of maize hybrids could be low when grown below optimum management practices. Use of improved varieties and optimum nitrogen fertilizer application practices are unlocking the high yielding potential of hybrids maize. With these in view, a field experiment was executed on farmers' field to determine the effect of varieties and nitrogen fertilizer rate on yield and yield components of maize in two cropping seasons. It is laid out with randomized complete block design in factorial arrangement with three replications. Five maize varieties (BH-540, BH-543, BH-661, BH-660, and BH-140) as main factor and two levels of nitrogen (55 and $110 \mathrm{Kg} \mathrm{N} \mathrm{ha}^{-1}$ ) as subfactor were used with one maize variety (BH-543) without fertilizer as control. Leaf area and leaf area index of maize varieties were significantly affected by application of nitrogen fertilizer rates. Interaction of maize varieties with nitrogen fertilizer rates significantly affected all yield and yield components of maize. Application of half and full recommended nitrogen fertilizer produced mean grain yield advantages of 31 and $41 \%$ over control. Therefore, application of half and full recommended nitrogen fertilizer for improved maize varieties has significantly improved grain yield and recommended for maize production in midaltitude area of western Ethiopia.
\end{abstract}

\section{Introduction}

Supplying nutritious, safe, and affordable food to a growing population is one of the far most burning issues currently facing Africa to fulfill food security in the region. Increase in soil degradation, salinization of irrigated areas, migration of youth to urban areas, and climate changes are among the many risks that are negatively affecting the agricultural production potential in Africa [1]. For agricultural production to keep pace with the growing global population, the use of chemical fertilizers will continue [2]. Adesemoye et al. [2] argued achieving sustainability; proper management techniques must be designed and implemented against the pollution potential of fertilizers. Despite the release of several high yielding maize (Zea mays L.) varieties to smallholder farmers and its high adoption rate, maize production levels in sub-Saharan Africa remain low [3].

Currently, the rate of $\mathrm{N}$ fertilizer application has increased tremendously, a trend which is expected to continue [4]. Lassaletta et al. [5] reported that only $47 \%$ of the reactive nitrogen added globally onto cropland is converted into harvested products, compared to $68 \%$ in the early 1960 s, while synthetic $\mathrm{N}$ fertilizer input increased by a factor of 9 over the same period. Nonetheless, in cereals, less than half of the applied $\mathrm{N}$ is recovered in the grain [6]. The remaining $\mathrm{N}$ is incorporated into soil organic matter or lost from farmlands through erosion, surface runoff, leaching, and gaseous $\left(\mathrm{NH}_{3}, \mathrm{~N}_{2} \mathrm{O}, \mathrm{NO}, \mathrm{NO}_{2}\right.$, or $\left.\mathrm{N}_{2}\right)$ emissions from 
the soil and plants [7]. Freney [8] reported that nitrogen might be lost by ammonia volatilization, during nitrification, by biological denitrification, and by chemodenitrification, leached whenever rainfall exceeds evaporation, and lost by runoff. Losses of nitrogen by denitrification can also vary widely ( $2 \%$ to $73 \%$ of nitrogen applied) depending on farming system and management $[6,9]$. More than half of the nitrogen used for crop fertilization is currently lost into the environment [5]. Thus, increasing $\mathrm{N}$ fertilizer use portends grave environmental consequences that are usually long-term and are seen as significant drivers of global change [10,11].

Recently, concerns about unbalanced use of fertilizers leading to environmental pollution have been globally expressed [12]. van der Velde et al. [13] reported that imbalances with other nutrients such as $\mathrm{P}$ could limit yield responses to $\mathrm{N}$ addition. Oosterhuis and Howard [14] reported on how to use efficient methods to reduce nutrient applications at the same time increasing or maintaining crop yield, and reducing nutrient losses and improving nutrient use efficiency are imperative. Lassaletta et al. [5] suggested that a further increase of nitrogen fertilization would result in a disproportionately low increase of crop production with further environmental alterations, unless cropping systems improve their efficiency substantially. $\mathrm{N}$ is the major limiting factor in agricultural production among mineral fertilizers $[10,15-17]$ and NUE is estimated to be far below $50 \%$ in cereal grains [6], improving that NUE is essential for improving overall productivity in maize [18]. Lassaletta et al. [5] stated that nutrient use efficiency acts as the indictor to check the ability of a crop to convert available nutrients to economic yield. Due to environmental and economic concerns with $\mathrm{N}$ fertilizers, improvement in nitrogen fertilizer application to maize varieties has become a desirable option for sustainable maize production. Therefore, the objective was to investigate the effects of varieties and nitrogen rate on yield and yield components of maize and recommend for producers better maize varieties with better nitrogen rate in order to increase yield and reduce environmental problems.

\section{Materials and Methods}

The experiment was conducted on six farmers' field around Bako Tibe in 2013 and 2014 cropping seasons. The area lies between $8^{\prime} 59^{\prime} 31^{\prime \prime} \mathrm{N}$ to $9^{\prime} 01^{\prime} 16 \mathrm{~N}$ latitude and $37^{\circ} 13^{\prime} 29 \mathrm{E}$ to $37^{\circ} 21^{\prime} \mathrm{E}$ longitude and at an altitude ranged from 1727 to 1778 meters above sea level, receiving mean annual rainfall of 1265 to $1293 \mathrm{~mm}$ with unimodal distribution [19, 20]. It has a warm humid climate with the mean minimum, maximum, and average air temperatures of $13.4,28.49$, and $20.95^{\circ} \mathrm{C}$, respectively [19], to $14,28.5$, and $21.2^{\circ} \mathrm{C}$ [20]. The soil type is brown clay loam Alfisol [21]. The experiment was laid out in factorial combinations with complete block design in three replications. Five maize varieties from subhumid mid altitude area were used as main factors. Two levels of nitrogen (half of the recommended ( $55 \mathrm{Kg} \mathrm{N} \mathrm{ha}^{-1}$ ) and recommended $\left(110 \mathrm{Kg} \mathrm{N} \mathrm{ha}^{-1}\right)$ ) were used as subfactor. One maize variety (BH-543) without fertilizer was used as control treatments. The maize varieties were BH-540, BH-543, BH-661, BH-660, and $\mathrm{BH}-140$. The total treatment combinations were 11 . The plot size was $5.1 \mathrm{~m} \times 4.5 \mathrm{~m}$. An improved seed each variety was planted in rows spaced at $75 \mathrm{~cm}$ between rows and $30 \mathrm{~cm}$ between plants. The weighed nitrogen rate was applied half at planting and remaining half at knee height. One hundred kilogram per hectare of Triple superphosphate (TSP) was applied for all treatments uniformly during planting. All other agronomic management practices were applied as per recommendation for the variety. The necessary data were collected at right time and crop growth stage.

2.1. Soil Sampling and Analysis. The soil samples were before treatment application from 10 sites randomly and composited one for analysis. The collected soil analysis was prepared following standard procedures and analyzed at Holleta and Debre Zeit Agricultural Research Center Soil and Plant Analysis Laboratory. Determination of soil particle size distribution was carried out using the hydrometer method [22]. The soil $\mathrm{pH}$ was measured with digital $\mathrm{pH}$ meter potentiometrically in the supernatant suspension of $1: 2.5$ soils to distilled water ratio. Organic carbon was determined following wet digestion methods as described by Walkley and Black [23] whereas Kjeldahl procedure was used for the determination of total nitrogen $(\mathrm{N})$ as described by Jackson [24]. The available P was measured by Bray II method [25] and available potassium (K) was measured by flame photometry. The steam distillation method was used for determination of $\mathrm{NO}_{3}{ }^{-} \mathrm{N}$ and $\mathrm{NH}_{4}{ }^{+} \mathrm{H}$ as described by Keeney and Nelson [26].

2.2. Crop Parameters. Leaf area and leaf area index at $50 \%$ tasseling and plant height and grain yield after maturity and harvesting of maize were collected at respective stage of the crop. The grain yield was harvested from the net plot $(3 \mathrm{~m}$ $\times 5.1 \mathrm{~m}=15 \mathrm{~m}^{2}$ ). The harvested grain yield was adjusted to $12.5 \%$ moisture level $[27,28]$. The adjusted seed yield at $12.5 \%$ moisture level per plot was converted to grain yield as kilogram per hectare.

2.3. Plant Tissue Sampling and Analysis. The tissue of maize was collected at $50 \%$ tasseling of maize from three replications and composited to after chopping. The grain of maize was collected after harvesting of the crop. The collected tissue and grain were prepared following standard procedures and analyzed at Holleta and Debre Zite Agricultural Research Center Soil and Plant Analysis Laboratory. The maize tissues and grain were subjected to wet digestion [29]. The N content of the plant tissue was determined by Kjeldahl procedure, whereas the $\mathrm{P}$ content was determined colorimetrically according to Murphy and Riley [30].

The $\mathrm{N}$ harvest index (NHI) at maturity was calculated by Jones et al. [31] and $\mathrm{N}$ accumulation $\left(\mathrm{kg} \mathrm{N} \mathrm{ha}^{-1}\right)$ in the shoots or grains was calculated by Seleiman et al. [32] and $\mathrm{Xu}$ et al. [33] as follows:

$\mathrm{N}$ harvest index

$$
=\frac{\text { Grain } \mathrm{N} \text { accumulation }\left(\mathrm{kg} \mathrm{ha}^{-1}\right)}{\text { Total } \mathrm{N} \text { accumulation }\left(\mathrm{kg} \mathrm{ha}^{-1}\right)},
$$


TABLE 1: Some physicochemical properties soil of farmer's field before planting maize in Bako Tibe districts, western Ethiopia.

\begin{tabular}{|c|c|c|c|c|c|c|c|c|c|c|c|c|}
\hline \multirow{2}{*}{ Farms } & \multirow{2}{*}{$\mathrm{pH}$} & \multirow{2}{*}{$\begin{array}{l}\mathrm{N} \\
(\%)\end{array}$} & \multirow{2}{*}{$\begin{array}{c}\mathrm{P} \\
(\mathrm{ppm})\end{array}$} & $\mathrm{OC}$ & $\mathrm{OM}$ & & K & $\mathrm{Na}$ & Exch. & $\mathrm{NO}_{3}{ }^{-} \mathrm{N}$ & $\mathrm{NH}_{4}^{+} \mathrm{N}$ & \multirow{2}{*}{ Texture } \\
\hline & & & & \multicolumn{2}{|c|}{$\%$} & \multicolumn{3}{|c|}{$\left(\right.$ meq 100 g soil $\left.^{-1}\right)$} & acidity & \multicolumn{2}{|c|}{$(\mathrm{ppm})$} & \\
\hline F-1 & 4.86 & 0.22 & 5.02 & 2.69 & 4.63 & 21.26 & 0.71 & 1.68 & 0.09 & 43.98 & trace & clay \\
\hline F-2 & 4.63 & 0.22 & 5.43 & 2.53 & 4.35 & 19.7 & 0.13 & 2.4 & 0.17 & 53.05 & 8.84 & Clay \\
\hline F-3 & 5.45 & 0.23 & 7.52 & 2.77 & 4.76 & 21.32 & 0.85 & 2.4 & 0.17 & 41.13 & 8.81 & clay \\
\hline F-4 & 5.4 & 0.17 & 6.27 & 2.07 & 3.56 & 38.12 & 0.85 & 1.68 & 0.08 & 30.17 & 6.03 & clay \\
\hline F-5 & 4.71 & 0.2 & 4.18 & 2.46 & 4.23 & 22.74 & 0.99 & 2.16 & 0.24 & 66.38 & 9.05 & clay \\
\hline F-6 & 5.44 & 0.18 & 5.67 & 2.22 & 3.82 & 36.5 & 0.56 & 1.44 & 0.12 & 41.13 & 11.75 & clay \\
\hline
\end{tabular}

Farm 1-6 = farmers' names (Takele Uluma, Adisu Fufa, Adisu Likessa, Mulatu shukar, Tesfaye Tsagaye, and Gutu Tolera).

where the total $\mathrm{N}$ accumulation includes all $\mathrm{N}$ that accumulated in leaves, stem, shank, cobs, and husk organs in addition to the grain.

$$
\begin{aligned}
& \text { Shoot } \mathrm{N} \text { accumulation }(\mathrm{kg} \mathrm{ha} \\
& = \\
& =\frac{\text { shoot } \mathrm{N} \text { content }\left(\mathrm{g} \mathrm{kg}^{-1}\right) \times \operatorname{shoot~DM~}\left(\mathrm{kg} \mathrm{ha}^{-1}\right)}{1000} \\
& \text { Grain } \mathrm{N} \text { accumulation }\left(\mathrm{kg} \mathrm{ha}^{-1}\right) \\
& =\frac{\text { grain } \mathrm{N} \text { content }\left(\mathrm{g} \mathrm{kg}^{-1}\right) \times \text { grain DM }\left(\mathrm{kg} \mathrm{ha}^{-1}\right)}{1000} .
\end{aligned}
$$

The data analyses for agronomic data were carried out using statistical packages and procedures of SAS computer software [34]. Mean separation was done using least significance difference (LSD) procedure at 5\% probability level [35].

2.4. Economic Analysis. Partial budget and marginal rate of return analysis and maize grain yield were valued at an average open market price of EB 375 per $100 \mathrm{~kg}$ for the last 5 years. Labour cost for field operation was EB 21 per manday. The yield was adjusted down by $10 \%$ to reflect actual production conditions [36]. The cost of fertilizer (urea and DAP) was EB 1275 and 1500 per $100 \mathrm{~kg}$ with current market price.

\section{Result and Discussion}

3.1. Some Soil Chemical and Physical Properties of the Study Area. The result of soil chemical and physical properties of different farm field's soil has been indicated in Table 1 . All the six-farm soil was clay in textural classes. The soil $\mathrm{pH}$ in $\mathrm{H}_{2} \mathrm{O}$ was ranged from 4.63 to 5.45 found in very strongly acidic to moderately acidic $[37,38]$.

Total $\mathrm{N}$ and $\mathrm{P}$ were ranged from 0.17 to $0.23 \%$; and 4.18 to $7.52 \mathrm{ppm}$ (Table 1). The total $\mathrm{N}$ concentrations for all six farms were found in very low, medium to high range [3739]. The extractable phosphorus concentration was found in low to medium range $[37,38]$. The different farm fields were needs different rates of nitrogen and phosphorous fertilizer management for maize. The organic carbon and organic matter concentrations were ranged from 2.07 to 2.77 and 3.56 to $4.76 \%$, which is found low to medium range $[37,38]$. The
CEC concentration was ranged from 19.7 to $38.5 \mathrm{cmol}^{+} \mathrm{kg}^{-1}$ and found in medium to high range $[37,38]$. Horneck et al. [40] soils with high clay and/or organic matter content have high CEC. The different farm soil was varied in nutrient holding capacity and organic matter contents based on CEC of the soil. Therefore, the six-farm soil required different soil fertility management practices for crop productions. The $\mathrm{NO}_{3}{ }^{-} \mathrm{N}$ concentration of the six-farm soil was ranged between 30.17 and $66.38 \mathrm{ppm}$ (Table 1), found in high to very high range [41, 42]; excessive range [43]. The $\mathrm{NH}_{4}{ }^{+} \mathrm{N}$ concentration of the soil was ranged from trace to $11.75 \mathrm{ppm}$ (Table 1) found in optimum range [40]. The $\mathrm{NO}_{3}{ }^{-} \mathrm{N}$ and $\mathrm{NH}_{4}{ }^{-} \mathrm{N}$ concentrations of the soils were found in optimum range for sustainable maize production.

3.2. Mean Leaf Area and Leaf Area Index of Maize. Mean leaf area and leaf area index of maize were significantly affected by use of varieties in three farms (Table 2), indicating variations of leaf size of different varieties of maize among farmers' field. Higher leaf area and leaf area index of $7246 \mathrm{~cm}^{2}$ and 3.86 followed by $7112 \mathrm{~cm} 2$ and 3.79 were recorded from BH-661 followed by BH-660. This indicates that the two varieties were performed better than other varieties in leaf width and length and also capture more solar radiation to produce more carbohydrates. All varieties produced higher leaf area and leaf area index under nitrogen applications indicating significant role of nitrogen for leaf development of maize varieties. Consider that optimum nitrogen application was very crucial for maize production to capture light to produce more photosynthesis. Applications of different rates of nitrogen were nonsignificantly affected mean leaf area and leaf area index maize at individual farms (Table 2). Combined mean of leaf area and leaf area index were significantly affected by rates applied nitrogen. Significantly higher mean leaf area and leaf area index of $7156 \mathrm{~cm} 2$ and 3.82 was recorded from application of recommended $\left(110 \mathrm{~kg} \mathrm{~N} \mathrm{ha}^{-1}\right)$ applied compared to half recommended. Leaf area and leaf area index advantage of 5.73 and $5.82 \%$ was recorded from full recommended nitrogen applied compared to half recommended $\mathrm{N}$. This indicates that application of nitrogen was contributed to higher leaf size to capture light for photosynthesis.

Interaction of maize varieties by nitrogen rates significantly affected mean leaf area and leaf area index of maize varieties (Table 3). Significantly higher mean leaf area 


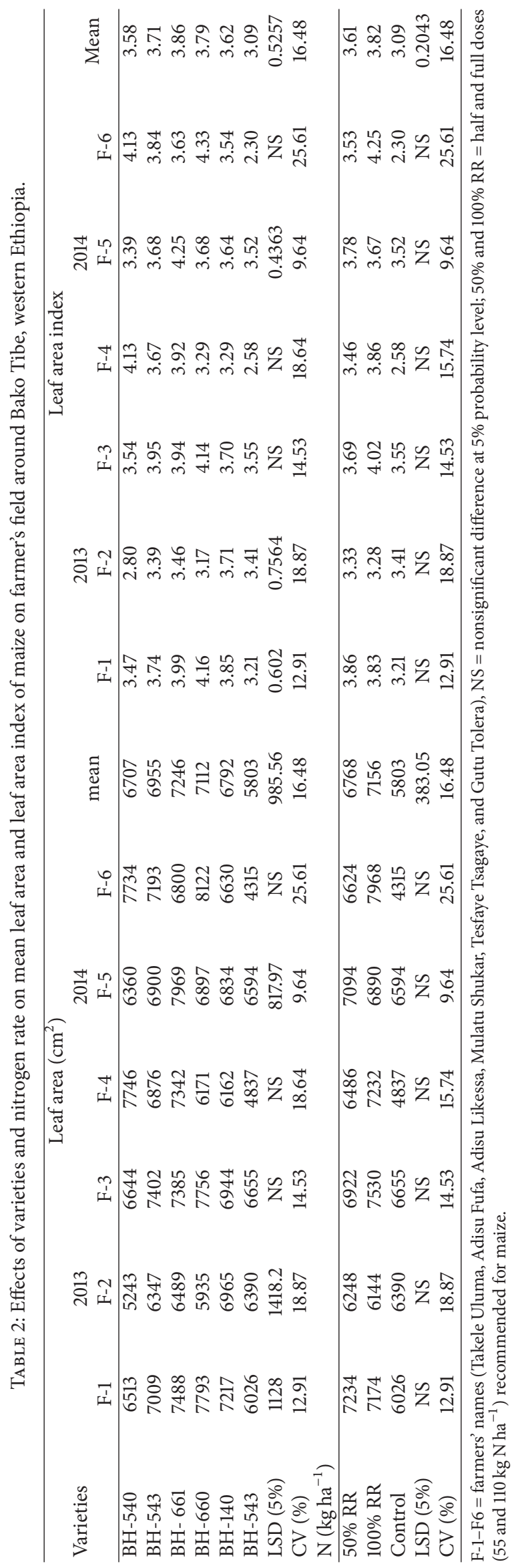




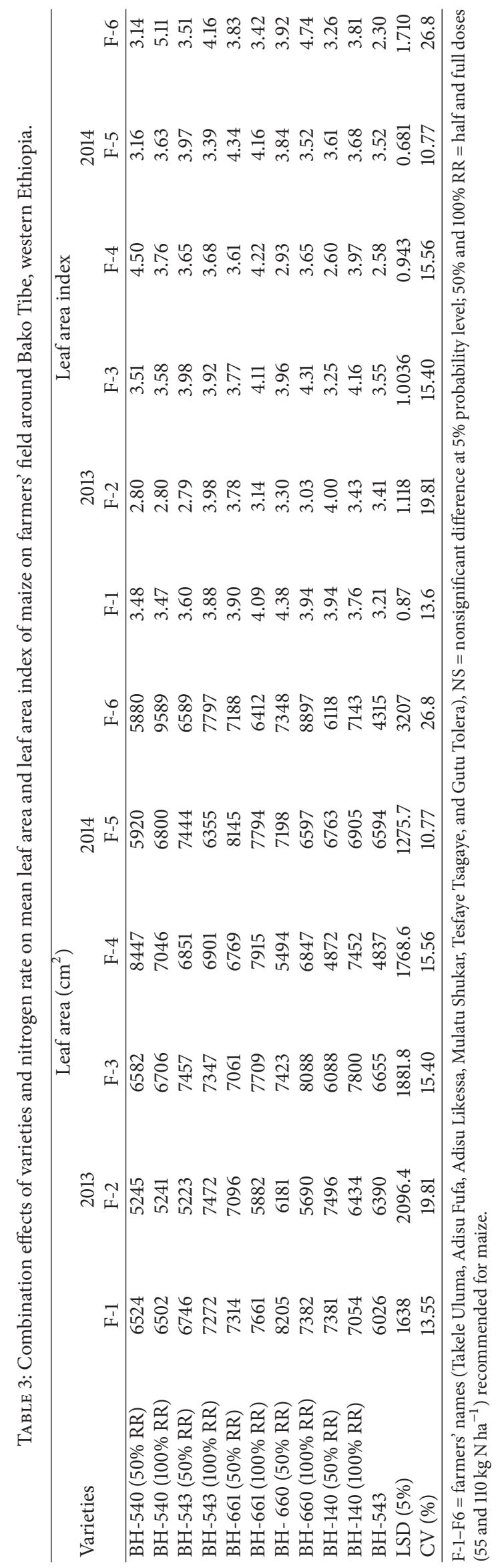


TABLE 4: Effects of varieties and nitrogen rate on mean plant height of maize on farmer's field around Bako Tibe, western Ethiopia.

\begin{tabular}{|c|c|c|c|c|c|c|c|}
\hline \multirow{3}{*}{ Varieties } & \multicolumn{7}{|c|}{ Plant height $(\mathrm{cm})$} \\
\hline & \multicolumn{3}{|c|}{2013} & \multicolumn{3}{|c|}{2014} & \multirow{2}{*}{ Mean } \\
\hline & F-1 & $\mathrm{F}-2$ & F-3 & F-4 & F-5 & F-6 & \\
\hline BH-540 & 263 & 242 & 268 & 260 & 270 & 266 & 261 \\
\hline BH-543 & 266 & 258 & 271 & 268 & 278 & 267 & 268 \\
\hline BH- 661 & 301 & 279 & 306 & 288 & 308 & 312 & 299 \\
\hline BH-660 & 259 & 271 & 297 & 263 & 263 & 312 & 278 \\
\hline $\mathrm{BH}-140$ & 258 & 242 & 263 & 284 & 266 & 266 & 263 \\
\hline $\mathrm{BH}-543$ & 276 & 244 & 274 & 273 & 254 & 240 & 260 \\
\hline LSD (5\%) & 18.3 & 19.391 & 17.705 & 7.0071 & 15.804 & 19.931 & 8.1063 \\
\hline CV (\%) & 5.6 & 6.19 & 5.19 & 5.480 & 4.7 & 5.78 & 5.34 \\
\hline \multicolumn{8}{|l|}{$\mathrm{N}\left(\mathrm{kg} \mathrm{ha}^{-1}\right)$} \\
\hline $50 \% \mathrm{RR}$ & 272 & 254 & 282 & 268 & 271 & 277 & 271 \\
\hline $100 \% \mathrm{RR}$ & 267 & 263 & 281 & 277 & 283 & 292 & 277 \\
\hline Control & 276 & 244 & 274 & 273 & 254 & 240 & 260 \\
\hline LSD (5\%) & NS & NS & NS & NS & 9.9955 & 12.605 & 4.4317 \\
\hline CV (\%) & 5.6 & 6.19 & 5.19 & 6.38 & 4.7 & 5.78 & 5.34 \\
\hline
\end{tabular}

F-1-F6 = farmers' names (Takele Uluma, Adisu Fufa, Adisu Likessa, Mulatu Shukar, Tesfaye Tsagaye, and Gutu Tolera), NS = nonsignificant difference at 5\% probability level; $50 \%$ and $100 \%$ recommended nitrogen rate $\left(110 \mathrm{~kg} \mathrm{~N} \mathrm{ha}^{-1}\right)$.

and leaf area index was achieved from all maize varieties applied with full recommended nitrogen rates. Furthermore, maize varieties planted with half and full recommended nitrogen applied nitrogen were given higher leaf area and leaf area index as compared to maize planted without nitrogen application. Significantly higher mean leaf area and leaf area index was ranged from 5803 to $7262 \mathrm{~cm}^{2}$ and 3.09 to 3.87 , respectively (Table 3 ). Application of optimum nitrogen to different maize varieties was desirable to have higher leaf size to capture solar energy for better photosynthesis to produce carbohydrate.

3.3. Mean Plant Height of Maize. Mean plant height of maize varieties was significantly different among varieties. Significantly higher, mean plant height of maize varieties were recorded from $\mathrm{BH}-661, \mathrm{BH}-660$, and $\mathrm{BH}-543$ varieties of maize in descending order (Table 4). This specifies that morphological variation was observed among maize varieties on different farmer's field. Consider that height of maize varieties was crucial to make hybrid of maize to avoid logging of maize without windbreaks. Mean plant height of maize was significantly affected by application of nitrogen on farms 5 and 6 and combined over farms (Table 4). Significantly higher combined mean plant height was recorded from maize varieties planted with full recommended rates of nitrogen. Application of nitrogen had a significant role in height maize varieties.

Interaction of maize varieties by nitrogen rates was significantly affected mean plant height of maize varieties among farmers field and combined over locations (Table 5). Significantly a higher, mean number of plant heights of maize varieties were recorded from BH-661, BH-660, and BH-543 varieties of maize in descending order (Table 5). Backcrosses of taller varieties were desirable to avoid logging of maize varieties in nonwindbreak farms.

3.4. Mean Grain Yield of Maize. Mean grain yield of maize was significantly different among varieties, across farms, and combined over farms (Table 6). This indicates that there were variations among farmers field with fertility status and management system applied to maize too. Raun et al. [44] reported that indigenous soil $\mathrm{N}$ across the landscape can vary severalfold, resulting in very different $\mathrm{N}$ recommendations depending on the location within the field. This indeed justifies the need site based fertilizer management and variety recommendation to farmers for sustainable maize production in the agroecology. Different varieties were given different yield across farms. Maize varieties BH-661 > BH-660 > BH$540>\mathrm{BH}-543>\mathrm{BH}-140$ in order produced better mean grain yield. All varieties produced significantly higher mean grain yield as compared to maize varieties planted without nitrogen fertilizer application. Combined mean grain yield advantage of 24 to $66 \%$ was achieved from maize varieties planted with nitrogen application as compared to control (Table 6). BH-661 followed by BH-660 significantly produced higher combined mean grain yield maize and was recommended for farmers to produce higher mean grain yield in area. Farmers should use maize varieties BH-661 > BH-660 > BH$540>$ BH-543 > BH-140, importance in descending order for alternative options.

Mean grain yield of maize varieties was significantly influenced by application nitrogen rates (Table 6). Significantly, higher mean grain yield was harvested from maize varieties planted with application of full recommended $\left(110 \mathrm{~kg} \mathrm{~N} \mathrm{ha}^{-1}\right)$ nitrogen rate compared to half nitrogen rate. Higher mean grain yield of maize varieties was obtained from half and 
TABLE 5: Combination effects of varieties and nitrogen rate on mean plant height of maize on farmer's field around Bako Tibe, western Ethiopia.

\begin{tabular}{|c|c|c|c|c|c|c|c|}
\hline \multirow{3}{*}{ Maize varieties with $\mathrm{N}$ rates } & \multicolumn{7}{|c|}{ Plant height $(\mathrm{cm})$} \\
\hline & \multicolumn{3}{|c|}{2013} & \multicolumn{3}{|c|}{2014} & \multirow{2}{*}{ Mean } \\
\hline & F-1 & F-2 & F-3 & $\mathrm{F}-4$ & F-5 & F-6 & \\
\hline BH-540 (50\% RR) & 256 & 233 & 261 & 256 & 262 & 253 & 254 \\
\hline BH-540 (100\% RR) & 269 & 250 & 274 & 263 & 279 & 278 & 269 \\
\hline BH-543 (50\% RR) & 263 & 254 & 273 & 255 & 268 & 257 & 262 \\
\hline BH-543 (100\% RR) & 268 & 262 & 269 & 282 & 288 & 277 & 274 \\
\hline BH-661 (50\% RR) & 302 & 271 & 305 & 297 & 312 & 311 & 300 \\
\hline BH-661 (100\% RR) & 299 & 286 & 307 & 280 & 304 & 312 & 298 \\
\hline BH- 660 (50\% RR) & 282 & 272 & 311 & 254 & 256 & 300 & 279 \\
\hline BH-660 (100\% RR) & 236 & 271 & 284 & 272 & 270 & 324 & 276 \\
\hline BH-140 (50\% RR) & 255 & 238 & 258 & 280 & 258 & 265 & 259 \\
\hline BH-140 (100\% RR) & 261 & 245 & 268 & 287 & 273 & 267 & 267 \\
\hline $\mathrm{BH}-543$ & 276 & 244 & 274 & 273 & 254 & 240 & 260 \\
\hline LSD (5\%) & 24.904 & 33.317 & 24.512 & NS & 21.057 & 27.634 & 10.553 \\
\hline CV (\%) & 5.42 & 7.61 & 5.130 & 7.077 & 4.498 & 5.785 & 5.86 \\
\hline
\end{tabular}

F-1-F6 = farmers' names (Takele Uluma, Adisu Fufa, Adisu Likessa, Mulatu Shukar, Tesfaye Tsagaye, and Gutu Tolera), NS = nonsignificant difference at $5 \%$ probability level; $50 \%$ and $100 \% \mathrm{RR}=$ half and full doses $\left(55\right.$ and $\left.110 \mathrm{~kg} \mathrm{~N} \mathrm{ha}^{-1}\right)$ recommended for maize.

TABLE 6: Effects of varieties and nitrogen rate on mean number of grain yield of maize on farmer's field around Bako Tibe, western Ethiopia.

\begin{tabular}{|c|c|c|c|c|c|c|c|}
\hline \multirow{3}{*}{ Varieties } & \multicolumn{7}{|c|}{ Grain yield $\left(\mathrm{kg} \mathrm{ha}^{-1}\right)$} \\
\hline & \multicolumn{3}{|c|}{2013} & \multicolumn{3}{|c|}{2014} & \multirow{2}{*}{ Mean } \\
\hline & F-1 & $\mathrm{F}-2$ & F-3 & F-4 & F-5 & F-6 & \\
\hline $\mathrm{BH}-540$ & 4114 & 2089 & 4751 & 2655 & 4518 & 5282 & 3901 \\
\hline BH-543 & 4988 & 2566 & 4644 & 2999 & 3731 & 4372 & 3883 \\
\hline ВН-661 & 6546 & 3050 & 4691 & 4193 & 5643 & 6052 & 5029 \\
\hline BH-660 & 3216 & 2509 & 4425 & 3447 & 4972 & 5867 & 4073 \\
\hline BH-140 & 4113 & 1754 & 4878 & 3171 & 4411 & 4223 & 3758 \\
\hline BH-543 & 3796 & 1870 & 3659 & 3941 & 3350 & 1556 & 3029 \\
\hline LSD (5\%) & 841.3 & 176.7 & 349.1 & 178.72 & 327.97 & 549.58 & 196.27 \\
\hline CV (\%) & 15.54 & 6.07 & 6.27 & 5.84 & 5.81 & 8.71 & 5.68 \\
\hline \multicolumn{8}{|l|}{$\mathrm{N}\left(\mathrm{kg} \mathrm{ha}^{-1}\right)$} \\
\hline $50 \% \mathrm{RR}$ & 4705 & 2208 & 4397 & 3159 & 4535 & 4806 & 3968 \\
\hline $100 \% \mathrm{RR}$ & 4485 & 2579 & 4958 & 3427 & 4774 & 5513 & 4289 \\
\hline Control & 3796 & 1870 & 3659 & 3941 & 3350 & 1556 & 3029 \\
\hline LSD (5\%) & 532.07 & 111.76 & 220.79 & 147.52 & 207.43 & 347.59 & 113.04 \\
\hline CV (\%) & 15.54 & 6.07 & 6.27 & 5.84 & 5.81 & 8.71 & 5.68 \\
\hline
\end{tabular}

F-1-F6 = farmers' names (Takele Uluma, Adisu Fufa, Adisu Likessa, Mulatu Shukar, Tesfaye Tsagaye, and Gutu Tolera), NS = nonsignificant difference at $5 \%$ probability level; $50 \%$ and $100 \% \mathrm{RR}=$ half and full doses $\left(55\right.$ and $\left.110 \mathrm{~kg} \mathrm{~N} \mathrm{ha}^{-1}\right)$ recommended for maize.

full recommended nitrogen fertilizer applied as compared to maize variety planted without nitrogen in all farms except farm 4 . This indicates that maize planted in farm 4 was not responding nitrogen fertilizer application, which might be due to very poor fertility status of the soil and termite infestation problems observed in the farm. Higher mean grain yield advantages which were ranged from 18 to $209 \%$ were obtained among different farms with half recommended nitrogen as compared to maize variety planted without nitrogen (Table 6). Maize varieties planted with full recommended $\left(110 \mathrm{~kg} \mathrm{~N} \mathrm{ha}^{-1}\right)$ were given significantly higher mean grain yield advantages ranging from 18 to $254 \%$ among farms as compared to maize variety planted without nitrogen fertilizer (Table 6). Combined mean grain yield advantages of 31 and $42 \%$ across farms were produced from maize planted with half and full recommended nitrogen applied as compared to maize varieties planted without nitrogen. Furthermore, application of full recommended nitrogen across farms gave grain yield advantage of $8 \%$ as compared to maize planted with half recommended nitrogen applied.

Interaction maize varieties with nitrogen rate significantly affected mean grain yield of maize among farms and 
TABLE 7: Combination effects of varieties and nitrogen rate on mean grain yield and thousand seed weight of maize on farmer's field around Bako Tibe, western Ethiopia.

\begin{tabular}{|c|c|c|c|c|c|c|c|}
\hline \multirow{3}{*}{ Maize varieties with $\mathrm{N}$ rates } & \multicolumn{7}{|c|}{ Grain yield $\left(\mathrm{kg} \mathrm{ha}^{-1}\right)$} \\
\hline & \multicolumn{3}{|c|}{2013} & \multicolumn{3}{|c|}{2014} & \multirow{2}{*}{ Mean } \\
\hline & F-1 & $\mathrm{F}-2$ & F-3 & F-4 & F-5 & F-6 & \\
\hline BH-540 (50\% RR) & 3633 & 1894 & 5057 & 2613 & 3904 & 4880 & 3663 \\
\hline BH-540 (100\% RR) & 4595 & 2283 & 4446 & 2696 & 5132 & 5684 & 4139 \\
\hline BH-543 (50\% RR) & 4516 & 2455 & 4141 & 2990 & 4043 & 4383 & 3755 \\
\hline BH-543 (100\% RR) & 5459 & 2678 & 5147 & 3009 & 3419 & 4361 & 4012 \\
\hline BH-661 (50\% RR) & 6719 & 2628 & 4323 & 4457 & 5472 & 5556 & 4859 \\
\hline BH-661 (100\% RR) & 6373 & 3472 & 5060 & 3928 & 5814 & 6548 & 5199 \\
\hline BH-660 (50\% RR) & 3872 & 2567 & 4107 & 3432 & 5042 & 5155 & 4029 \\
\hline BH-660 (100\% RR) & 2561 & 2451 & 4742 & 3462 & 4902 & 6579 & 4116 \\
\hline BH-140 (50\% RR) & 4788 & 1494 & 4359 & 2302 & 4216 & 4053 & 3535 \\
\hline BH-140 (100\% RR) & 3437 & 2013 & 5398 & 4039 & 4605 & 4393 & 3981 \\
\hline BH-543 & 3796 & 1870 & 3659 & 3941 & 3350 & 1556 & 3029 \\
\hline LSD (5\%) & 1154.8 & 242.2 & 537.8 & 361 & 456.19 & 960.75 & 656.99 \\
\hline CV (\%) & 15.41 & 6.05 & 7.01 & 6.33 & 5.9 & 11.45 & 10.08 \\
\hline
\end{tabular}

F-1-F6 = farmers' names (Takele Uluma, Adisu Fufa, Adisu Likessa, Mulatu Shukar, Tesfaye Tsagaye, and Gutu Tolera). NS = nonsignificant difference at 5\% probability level; $50 \%$ and $100 \% \mathrm{RR}=$ half and full doses (55 and $110 \mathrm{~kg} \mathrm{Nha}^{-1}$ ) recommended for maize.

were combined across farms (Table 7). This is implying that the responses of different maize varieties to rates of $\mathrm{N}$ fertilizer were different. Le Gouis et al. [45] confirmed that there is a genetic variability for grain yield at a low $\mathrm{N}$ level and that the genotype $\times \mathrm{N}$ level interaction is significant. Average mean grain yield was ranged from 2346 to $4832 \mathrm{~kg} \mathrm{ha}^{-1}$ among farms (Table 7). This indicates variation of soil fertility status and management practices applied among each farms. Farm and/or soil test based fertilizer recommendations were required for sustainable maize production in the area. Maize varieties planted with half $\left(55 \mathrm{~kg} \mathrm{~N} \mathrm{ha}^{-1}\right)$ recommended nitrogen application were given mean grain yield advantages ranging from 16 to $60 \%$ as compared to maize planted without nitrogen application. $\mathrm{BH}-543, \mathrm{BH}-660$, and $\mathrm{BH}-661$ varieties were better nitrogen efficient varieties among maize varieties used. Significantly higher mean grain yield advantages ranging from 31 to $72 \%$ were produced from maize varieties planted with full $\left(110 \mathrm{~kg} \mathrm{~N} \mathrm{ha}^{-1}\right)$ recommended nitrogen fertilizer as compared to control. The grain yield of maize was increased as the rate of nitrogen fertilizer increased [46]. Maize varieties BH-661 followed $\mathrm{BH}-660$ were ranked first and second among the maize varieties used. Higher mean grain yield and nitrogen use efficiency were obtained from $\mathrm{BH}-661$ followed by $\mathrm{BH}-$ 660 varieties of maize. This indicates that maize varieties with higher grain yield potential had higher nitrogen use efficiency.

3.5. Shoot and Grain $N$ Accumulation and $N$ Harvest Index of Maize. The mean shoot $\mathrm{N}$ accumulation, grain $\mathrm{N}$ accumulation, and $\mathrm{N}$ harvest index of maize varieties are indicated in Tables 8 and 9. Nitrogen harvest index of maize varieties was varied across farms, varieties, and nitrogen fertilizer application. Nitrogen harvest index of maize varieties was ranged between 0.16 and $0.23 \%$. Farm one followed by farm 4 produced higher nitrogen harvest index of maize varieties across farms. Higher nitrogen harvest index of maize varieties was obtained with half recommended nitrogen fertilizer as compared to maize varieties planted with full recommended nitrogen fertilizer application. Moser [46] found that maize varieties differed significantly in $\mathrm{N}$ harvest index and the $\mathrm{N}$ harvest index decreased as the rate of nitrogen fertilizer increased. Maize varieties planted with half recommended nitrogen fertilizer produced $1.06 \%$ nitrogen harvest index advantages over full recommended nitrogen fertilizer application. NHI reflects the grain protein content and thus the grain nutritional quality [47]. Maize varieties planted without nitrogen fertilizer application were given $16 \%$ nitrogen harvest index over maize varieties planted with half and full recommended nitrogen fertilizer application.

The mean shoot $\mathrm{N}$ accumulation of maize varieties was varied across farms and among varieties with nitrogen fertilizer application. Higher shoot nitrogen accumulation ranging from 40 to 87 was obtained from among all farms (Table 9). Except some farms, higher shoot accumulation was obtained from maize varieties planted with half and full recommended nitrogen fertilizer application as compared to maize planted without fertilizer application. Mean shoot $\mathrm{N}$ accumulation of 64 and 74 was obtained from maize varieties planted with half and full recommended fertilizer application. Application of half and full recommended nitrogen fertilizer to maize varieties was given higher shoot nitrogen accumulation of 56 and $881 \%$ over maize varieties planted without nitrogen fertilizer application. Similarly, Anbessa and Juskiw [7] found that biomass $\mathrm{N}$ yield was increased with the rate of $\mathrm{N}$ fertilizer. The correlation coefficients between maize productivity and $\mathrm{N}$ accumulated in shoots (leaves, corncobs, straws, and stems) were high [48]. Moser [46] found that maize varieties differed significantly in shoot $\mathrm{N}$ concentration and shoot $\mathrm{N}$ accumulation and shoot $\mathrm{N}$ concentration was increased with 
TABLE 8: Effects of varieties and nitrogen rate on $\mathrm{N}$ harvest index of maize on farmer's field around Bako Tibe, western Ethiopia.

\begin{tabular}{|c|c|c|c|c|c|c|c|}
\hline \multirow{3}{*}{ Maize varieties with $\mathrm{N}$ rates } & \multicolumn{7}{|c|}{$\mathrm{N}$ harvest index $\left(\mathrm{kg} \mathrm{ha}^{-1}\right)$} \\
\hline & \multicolumn{3}{|c|}{2013} & \multicolumn{3}{|c|}{2014} & \multirow{2}{*}{ Mean } \\
\hline & Farm 1 & Farm 2 & Farm 3 & Farm 4 & Farm 5 & Farm 6 & \\
\hline BH-540 (50\% RR) & 0.18 & 0.11 & 0.19 & 0.21 & 0.25 & 0.22 & 0.19 \\
\hline BH-540 (100\% RR) & 0.22 & 0.27 & 0.11 & 0.21 & 0.18 & 0.16 & 0.19 \\
\hline BH-543 (50\% RR) & 0.35 & 0.19 & 0.13 & 0.15 & 0.19 & 0.21 & 0.21 \\
\hline BH-543 (100\% RR) & 0.15 & 0.16 & 0.15 & 0.19 & 0.11 & 0.14 & 0.15 \\
\hline BH-661 (50\% RR) & 0.34 & 0.26 & 0.11 & 0.22 & 0.17 & 0.18 & 0.21 \\
\hline BH-661 (100\% RR) & 0.30 & 0.29 & 0.31 & 0.22 & 0.24 & 0.14 & 0.25 \\
\hline BH- 660 (50\% RR) & 0.21 & 0.18 & 0.20 & 0.17 & 0.27 & 0.11 & 0.19 \\
\hline BH-660 (100\% RR) & 0.17 & 0.12 & 0.17 & 0.25 & 0.21 & 0.24 & 0.19 \\
\hline BH-140 (50\% RR) & 0.20 & 0.11 & 0.18 & 0.16 & 0.13 & 0.13 & 0.15 \\
\hline BH-140 (100\% RR) & 0.13 & 0.15 & 0.15 & 0.20 & 0.21 & 0.13 & 0.16 \\
\hline BH-543 & 0.30 & 0.26 & 0.22 & 0.21 & 0.18 & 0.12 & 0.22 \\
\hline
\end{tabular}

Farm 1-6 = farmers' names (Takele Uluma, Adisu Fufa, Adisu Likessa, Mulatu Shukar, Tesfaye Tsagaye, and Gutu Tolera); $50 \%$ and $100 \%$ RR = half and full doses (55 and $110 \mathrm{~kg} \mathrm{~N} \mathrm{ha}^{-1}$ ) recommended for maize.

increased rate of nitrogen. The average of $\mathrm{N}$ accumulation in shoots collected at harvesting was $69.7 \mathrm{ha}^{-1}$ [48]. Total amount shoot $\mathrm{N}$ accumulation increased as the rate of nitrogen fertilizer increased [46]. Duete et al. [49] found $\mathrm{N}$ accumulation in the maize shoots after the harvesting of 33.2 to $58.2 \mathrm{~kg} \mathrm{ha}^{-1}$ relative to levels of $180 \mathrm{~kg} \mathrm{ha}^{-1} \mathrm{~N}$ implying nitrogen fertilizer contributed maize dry biomass.

The mean grain nitrogen accumulation was varied across farms, varieties, and nitrogen fertilizer application. Mean grain $\mathrm{N}$ accumulation of $9,12,15,15,16$, and 17 was obtained from maize planted on farm 2, farm 4, farm 3, farm 5, farm 1, and farm 6, respectively. Farm 6 followed by farm 1 was given higher grain $\mathrm{N}$ accumulation as compared to other farms. This indicates that these two farms had better fertility potential to produce sustainable maize production in the region. All maize varieties were given higher $\mathrm{N}$ accumulation at full recommended nitrogen fertilizer application as compared to half recommended nitrogen application and without fertilizer $\mathrm{N}$ application. da Silva et al. [48] found that grain $\mathrm{N}$ accumulation was higher in all treatments with ammonium sulphate fertilization. The $\mathrm{N}$ accumulation in plants and grains was in agreement with the reports by Zotarelli et al. [50]. Grain N yield increased with the rate of $\mathrm{N}$ fertilizer and averaged over cultivars, and grain $\mathrm{N}$ yield was 94,126 , and $146 \mathrm{~kg} \mathrm{ha}^{-1}$ for the low, moderate, and high $\mathrm{N}$ regimes [7]. Mean grain $\mathrm{N}$ accumulation was ranged from 12 to 17 and 13 to 18 from maize varieties planted with half and full recommended nitrogen fertilizer application. The lowest and highest grain $\mathrm{N}$ accumulation were obtained from $\mathrm{BH}-$ 140 and BH-661 with half and full recommended nitrogen fertilizer application. Higher mean grain $\mathrm{N}$ accumulation of 27 and 38\% was obtained from maize varieties planted with half and full recommended nitrogen fertilizer application as compared to maize variety planted without nitrogen fertilizer application. This indicates that application nitrogen fertilizer significantly increased grain $\mathrm{N}$ accumulation of maize varieties. The $\mathrm{N}$ accumulation was higher when fertilization was completely applied at maize sowing or side dressing [48] and the average of $\mathrm{N}$ accumulation grains collected at harvesting was $78.8 \mathrm{~kg} \mathrm{ha}^{-1}$. Therefore, application of nitrogen fertilizer increased shoot and grain $\mathrm{N}$ accumulation of maize varieties. In conclusion, covering maize stalk after harvesting had a contribution to soil fertility management of the soil.

3.6. Effects of Varieties and $N$ Rates on Economic Viability of Maize Production. The economic analysis results for interaction effects of maize varieties with nitrogen fertilizer were indicated in Table 10. The highest net benefit of EB $15011 \mathrm{ha}^{-1}$ and marginal rate of return $345 \%$ was obtained from planting of BH-661 maize varieties with application of half-recommended $\left(55 \mathrm{~kg} \mathrm{Nha}^{-1}\right)$ rate. The marginal rate of returns 54, 76, and $143 \%$ was obtained from planting of $\mathrm{BH}$ 540, BH-543, and BH-660 maize varieties with application of half recommended nitrogen fertilizer. The values to cost ratio which were ranged from EB 2.32 to 10.81 per unit of investment were for recommended and half recommended nitrogen fertilizer rate. The economic net benefit of EB 13947, 12210, and $11285 \mathrm{ha}^{-1}$ was achieved from maize varieties $\mathrm{BH}-661$ planted with full recommended; $\mathrm{BH}-660$ and $\mathrm{BH}-$ 543 with half recommended nitrogen fertilizer (Table 10). This indicates that planting of maize varieties with half recommended nitrogen fertilizer was given higher economic benefits. The mean grain yield and economic return from planting of maize varieties with the application of half recommended nitrogen fertilizer were significantly higher than recommended rate. There four maize varieties (BH-540, $\mathrm{BH}-543, \mathrm{BH}-660$, and $\mathrm{BH}-661)$ were nitrogen use efficient and reduced environmental pollution. In contrary due to continuous cultivation, maize varieties in the filed application of nitrogen fertilizer may cause no response, which might be due to soil acidity and shortage other secondary macronutrients. Currently the Ethiopian Ministry of Agriculture is dealing with blended fertilizer NPS rather than NP and application of 


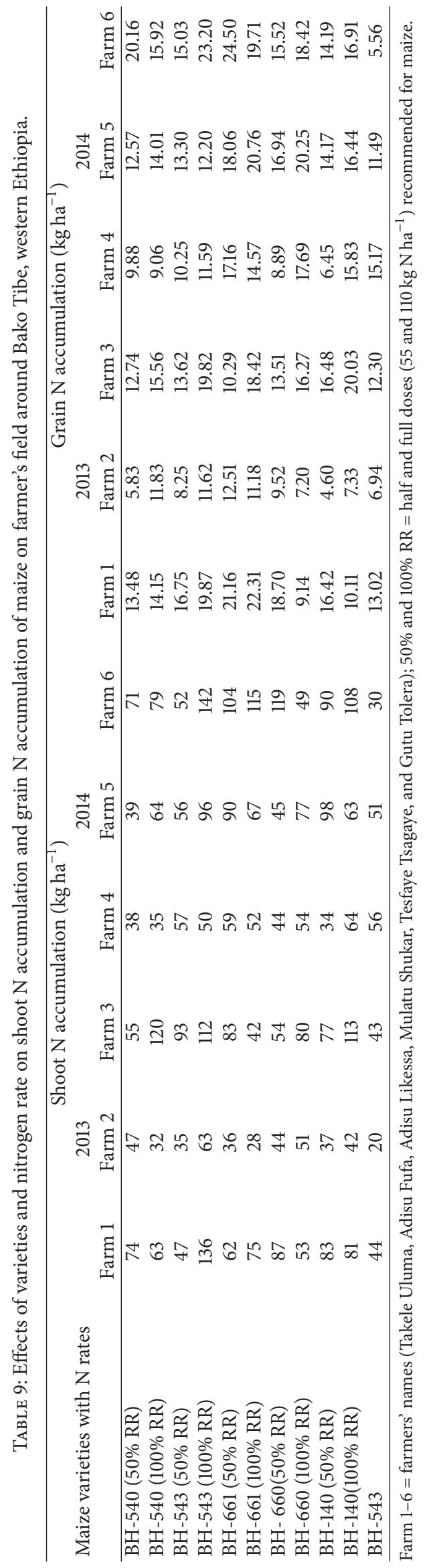




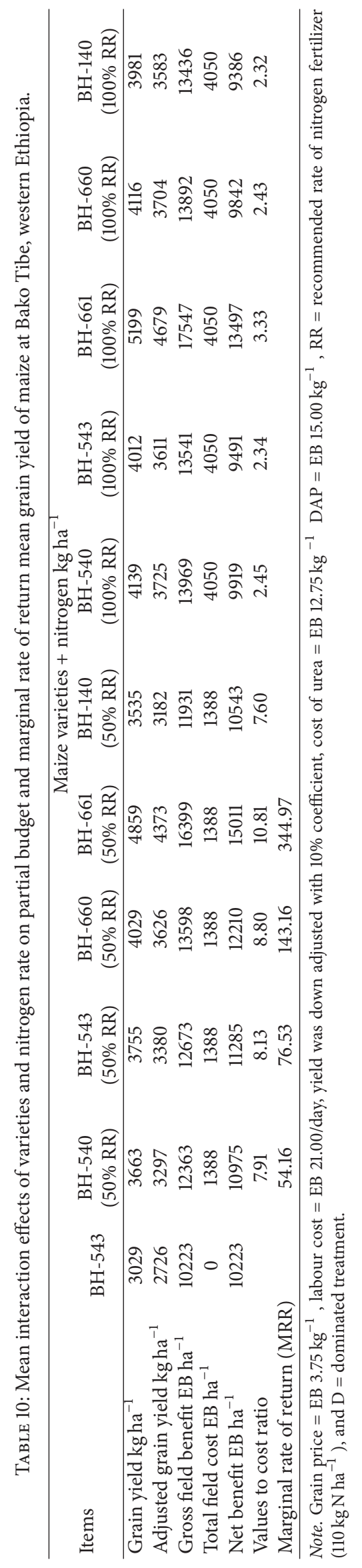


lime in acidity problem soil. Soil acidity, secondary nutrient limitations, and physical constraints problems which caused no response to NP fertilizer were stated by Vanlauwe et al. [51], and secondary macronutrients deficiencies in SSA is gradually becoming apparent. Soil acidification interferes with the availability of specific nutrients. Vanlauwe et al. [51] suggested that results from regional scale analysis have been valuable in informing policy on urgent need to support farmers to access improved seed and fertilizers to resolve soil fertility challenges underlying low crop productivity (e.g., increase fertilizer use to support crop production intensification, which led to the target of increasing fertilizer use in SSA to $50 \mathrm{~kg}$ nutrients per ha). Knowledge of integrating soil fertility management with varieties on how to adapt these practices to local conditions, aiming at maximizing agronomic use efficiency of the applied nutrients and improving crop productivity Vanlauwe et al. [51,52], was crucial for sustainable maize production. In addition assessing the blended application of secondary macronutrients into NP fertilizers and application of lime in acidity prone area like western Ethiopia at both regional and individual farm scales level would be recommended. Further investigation on recommended nitrogen fertilizer rate for maize production was advisable for agronomically, economical feasible and environmental sound sustainable maize production in western Ethiopia.

\section{Conclusion}

Soil fertility problem was alleviated using improved crop management practices. Maize varieties produced significantly different biological and grain yield. Application of nitrogen fertilizer was given significantly higher mean grain yield maize. Application of nitrogen fertilizer was increased shoot and grain $\mathrm{N}$ accumulation of maize varieties. Higher nitrogen harvest index of maize varieties was obtained with half recommended nitrogen fertilizer as compared to maize varieties planted with full recommended nitrogen fertilizer application. Planting of $\mathrm{BH}-661, \mathrm{BH}-660, \mathrm{BH}-540$, and $\mathrm{BH}-$ 543 maize varieties with half recommended nitrogen fertilizer rate was agronomically given higher grain yield and economical feasible for sustainable maize production. Thus, planting of maize varieties with optimum nitrogen application was far most important for sustainable maize production in the agroecology. In conclusion, the results' empathy of improved maize varieties with half and full recommended nitrogen fertilizer is recommended for sustainable maize production in the area.

\section{Conflicts of Interest}

The authors declare that there are no conflicts of interest regarding the publication of this paper.

\section{Acknowledgments}

The authors acknowledge Regional University Fund for Capacity Building in Agriculture, International Development Research Center, and Carnegie Doctoral Research Grant
Fund for funding the experiment. The authors are very grateful to Ambo Agricultural Research Center Management for providing them with all necessary equipment's and logistics during the research work. All the technical and field assistants of Land and Water Resources Research Process are also acknowledged for unreserved effort during executing the experiment. Ambo Plant Protection Research Center, Holleta and Debre Zeit Agricultural Research Center, and Soil and Plant Analysis Laboratory are acknowledged for their provision of laboratory service for soil. The authors want to thank Bako Tibe farmers for providing them with land for field research work and their assistance in field managements.

\section{References}

[1] AGRA, Africa Agriculture Status Report: Focus on Staple Crops. Nairobi, Kenya, 2013.

[2] A. O. Adesemoye, H. A. Torbert, and J. W. Kloepper, "Increased plant uptake of nitrogen from $15 \mathrm{~N}$-depleted fertilizer using plant growth-promoting rhizobacteria," Applied Soil Ecology, vol. 46, no. 1, pp. 54-58, 2010.

[3] S. Kalonga, Long term food security implications of top-down agricultural strategies in Malawi. Dissertation thesis at Surrey Institute of Global Economics Research, Worcester Park, UK, 2002.

[4] A. O. Adesemoye and J. W. Kloepper, "Plant-microbes interactions in enhanced fertilizer-use efficiency," Applied Microbiology and Biotechnology, vol. 85, no. 1, pp. 1-12, 2009.

[5] L. Lassaletta, G. Billen, B. Grizzetti, J. Anglade, and J. Garnier, "50 year trends in nitrogen use efficiency of world cropping systems: the relationship between yield and nitrogen input to cropland," Environmental Research Letters, vol. 9, no. 10, Article ID 105011, 2014.

[6] W. R. Raun and G. V. Johnson, "Improving nitrogen use efficiency for cereal production," Agronomy Journal, vol. 91, no. 3, pp. 357-363, 1999.

[7] Y. Anbessa and P. Juskiw, "Review: strategies to increase nitrogen use efficiency of spring barley," Canadian Journal of Plant Science, vol. 92, no. 4, pp. 617-625, 2012.

[8] J. R. Freney, Management practices to increase efficiency of fertilizer and animal nitrogen and minimize nitrogen loss to the atmosphere and groundwater. CSIRO Plant Industry, Canberra, A.C.T. 2601, Australia. pp. 22, 2013.

[9] J. N. Galloway, F. J. Dentener, D. G. Capone et al., "Nitrogen cycles: past, present, and future," Biogeochemistry, vol. 70, no. 2, pp. 153-226, 2004.

[10] P. M. Vitousek, J. D. Aber, R. W. Howarth et al., "Human alteration of the global nitrogen cycle: sources and consequences," Ecological Applications, vol. 7, no. 3, pp. 737-750, 1997.

[11] R. J. Diaz and R. Rosenberg, "Spreading dead zones and consequences for marine ecosystems," Science, vol. 321, no. 5891, pp. 926-929, 2008.

[12] O. H. Ahmed, G. Sumalatha, and A. M. Nik Muhamad, "Use of zeolite in maize (Zea mays) cultivation on nitrogen, potassium and phosphorus uptake and use efficiency," International Journal of Physical Sciences, vol. 5, no. 15, pp. 2393-2401, 2010.

[13] I. R. van der Velde, J. B. Miller, K. Schaefer, G. R. Van Der Werf, M. C. Krol, and W. Peters, "Terrestrial cycling of ${ }^{13} \mathrm{CO}_{2}$ by photosynthesis, respiration, and biomass burning in SiBCASA," Biogeosciences, vol. 11, no. 23, pp. 6553-6571, 2014. 
[14] D. M. Oosterhuis and D. D. Howard, "Evaluation of slow-release nitrogen and potassium fertilizers for cotton production," African Journal of Agricultural Research, vol. 3, no. 1, pp. 68-73, 2008.

[15] B. Hirel, J. Le Gouis, B. Ney, and A. Gallais, "The challenge of improving nitrogen use efficiency in crop plants: towards a more central role for genetic variability and quantitative genetics within integrated approaches," Journal of Experimental Botany, vol. 58, no. 9, pp. 2369-2387, 2007.

[16] M. Andrews and P. J. Lea, "Our nitrogen 'footprint': the need for increased crop nitrogen use efficiency," Annals of Applied Biology, vol. 163, no. 2, pp. 165-169, 2013.

[17] M. Andrews, J. A. Raven, and P. J. Lea, "Do plants need nitrate? the mechanisms by which nitrogen form affects plants," Annals of Applied Biology, vol. 163, no. 2, pp. 174-199, 2013.

[18] B. Hirel and A. Gallais, "Nitrogen use efficiency-Physiological, molecular and genetic investigations towards crop improvement," Advances in Maize, Society for Experimental Biology, vol. 3, pp. 285-310, 2011.

[19] MBARC, Meteorological data of Bako area for 1960-2014. Bako, Oromia, Etiopia, 2014.

[20] NMSA, Meteorological data of Ilu-Gelan area for 2009-2014. NMSA, Addis Ababa, Etiopia, 2014.

[21] L. Krogh and M. H. Greve, "Evaluation of World Reference Base for Soil Resources and FAO Soil Map of the World using nationwide grid soil data from Denmark," Soil Use and Management, vol. 15, no. 3, pp. 157-166, 1999.

[22] J. Dewis and F. Freitas, Physical and chemical methods of soil and water analysis. FAO Soil Bulletin No. 10. FAO, Rome, 1984.

[23] A. Walkley and I. Black, "An examination of the Degtjareff method for determining soil organic matter, and a proposed modification of the organic acid titration method," Soil Science, vol. 37, no. 1, pp. 29-38, 1934.

[24] M. L. Jackson, Soil chemical analysis, Prentice Hall, Inc, Engle Wood Cliffs, NJ, USA, 1958.

[25] R. H. Bray and L. T. Kurtz, "Determination of total, organic, and available forms of phosphorus in soils," Soil Science, vol. 59, no. 1, pp. 39-46, 1945.

[26] D. R. Keeney and D. W. Nelson, Nitrogen in Organic Forms. In: Page, A. L., R. H. Miller and Keeney. D. R. (Eds). Methods of Soil Analysis. Agronomy. Part II, No. 9, American Society of Agronomy. Madison, Wisconsin, USA, pp. 643-698, 1982.

[27] A. Birru, Agricultural Field Experiment Management Manual Part III. IAR (Institute of Agricultural Research). Addis Ababa, Ethiopia, pp. 35-42, 1979.

[28] L. A. Nelson, R. D. Voss, and J. Pesek, Agronomic and statistical evaluation of fertilizer response, 89 pp, 1985.

[29] J. B. Jones and V. W. Case, "Sampling, handling, and analyzing plant tissue samples," in Soil Testing and Plant Analysis, R. L. Westerman, Ed., SSSA Book Series, Soil Science Society of America, 1990.

[30] J. Murphy and J. P. Riley, "A modified single solution method for the determination of phosphate in natural waters," Analytica Chimica Acta, vol. 27, pp. 31-36, 1962.

[31] J. B. Jones, V. W. Case, and R. L. Westerman, "Sampling, handling and analyzing plant tissue samples," in Soil Testing and Plant Analysis, R. L. Westerman, Ed., pp. 389-447, Soil Sciences Society of American, 1990.

[32] M. F. Seleiman, A. Santanen, S. Jaakkola et al., "Biomass yield and quality of bioenergy crops grown with synthetic and organic fertilizers," Biomass \& Bioenergy, vol. 59, pp. 477-485, 2013.
[33] Z.-Z. Xu, Z.-W. Yu, and D. Wang, "Nitrogen translocation in wheat plants under soil water deficit," Plant and Soil, vol. 280, no. 1-2, pp. 291-303, 2006.

[34] SAS, SAS/STAT Software Syntax, Version 9.0. SAS Institute, Cary, NC. USA, 2004.

[35] R. G. D. Steel and J. H. Torrie, Principles of statistics: a biometrical approach, 2nd edition, 1980.

[36] CIMMYT, From Agronomic Data to Farmer Recommendations: An Economics Training Manual, 1988.

[37] J. R. London, Booker tropical soil manual: A handbook for soil survey and agricultural land evaluation in the tropics and subtropics. Longman, 1991.

[38] FAO, 1990. Guideline for Soil Description. Rome, Italy, 1990.

[39] R. C. Bruce and G. E. Rayment, Analytical methods and interpretations used by the Agricultural Chemistry Branch for Soil and Land Use Surveys. Queensland Department of Primary Industries. Bulletin QB8 (2004), 1982.

[40] D. A. Horneck, D. M. Sullivan, J. S. Owen, and J. M. Hart, Soil test interpretation guide. Oregon State University Extension Service, 2011.

[41] I. Bashour, "Fertility and fertilizer requirements. in," Rural integrated development of the mountains of northern Lebanon, 2002.

[42] FAO, Near East fertilizer-use manual. FAO/14152/F. Rome, Italy, 2006.

[43] E. S. Marx, J. Hart, and R. G. Stevens, Soil test interpretation guide. EC 1478. Oregon State University Extension service, 1999.

[44] W. R. Raun, I. Ortiz-Monasterio, and J. B. Solie, “Temporally and spatially dependent nitrogen management for diverse environments," Wheat Science and Trade, pp. 203-214, 2009.

[45] J. Le Gouis, D. Béghin, E. Heumez, and P. Pluchard, "Genetic differences for nitrogen uptake and nitrogen utilisation efficiencies in winter wheat," European Journal of Agronomy, vol. 12, no. 3-4, pp. 163-173, 2000.

[46] S. B. Moser, Effects of pre-anthesis drought stress and nitrogen on yield, nitrogen use efficiency, and grain minerals of tropical maize varieties. Dissertation for Award of PhD. degree Natural Sciences at Swiss federal Institute of Technology Zurich, 2004.

[47] T. R. Sinclair, L. C. Purcell, and C. H. Sneller, "Crop transformation and the challenge to increase yield potential," Trends in Plant Science, vol. 9, no. 2, pp. 70-75, 2004.

[48] M. A. G. da Silva, A. R. Mannigel, A. S. Muniz et al., "Ammonium sulphate on maize crops under no tillage," Bragantia, vol. 71, no. 1, pp. 90-97, 2012.

[49] R. R. C. Duete, T. Muraoka, E. C. Silva, P. C. O. Trivelin, and E. J. Ambrosano, "Manejo da adubação nitrogenada e utilização do nitrogênio $\left({ }^{15} \mathrm{~N}\right)$ pelo milho em Latossolo Vermelho," Revista Brasileira de Ciência do Solo, vol. 32, no. 1, pp. 161-171, 2008.

[50] L. Zotarelli, E. G. Cardoso, J. L. Piccinin et al., "Calibration of a Minolta SPAD-502 chlorophyll meter for evaluation of the nitrogen nutrition of maize," Revista Brasileira de Ciência do Solo, vol. 38, pp. 1117-1122, 2003.

[51] B. Vanlauwe, K. Descheemaeker, K. E. Giller et al., "Integrated soil fertility management in sub-Saharan Africa: unravelling local adaptation," SOIL Discussions, vol. 1, no. 1, pp. 1239-1286, 2014.

[52] B. Vanlauwe, J. Wendt, K. E. Giller, M. Corbeels, B. Gerard, and C. Nolte, "A fourth principle is required to define conservation agriculture in sub-Saharan Africa: the appropriate use of fertilizer to enhance crop productivity," Field Crops Research, vol.155, pp. 10-13, 2014. 


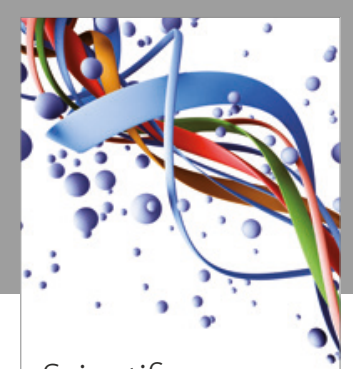

Scientifica
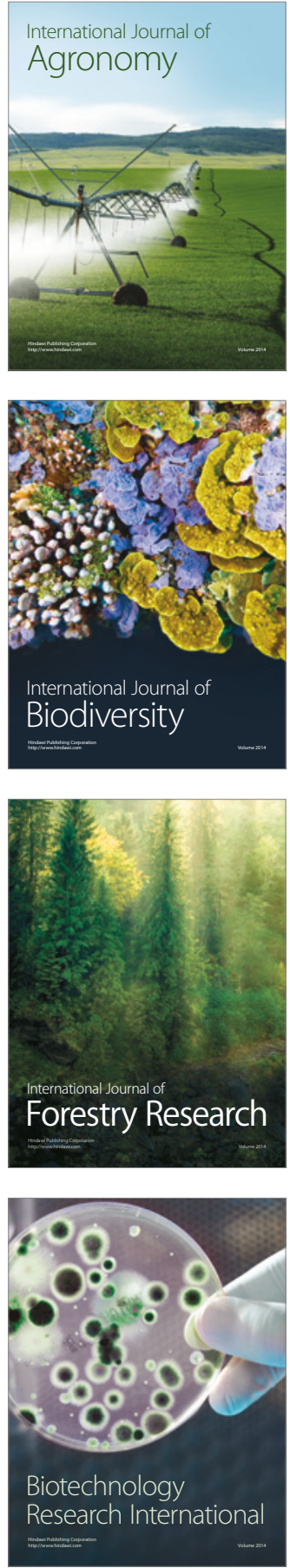
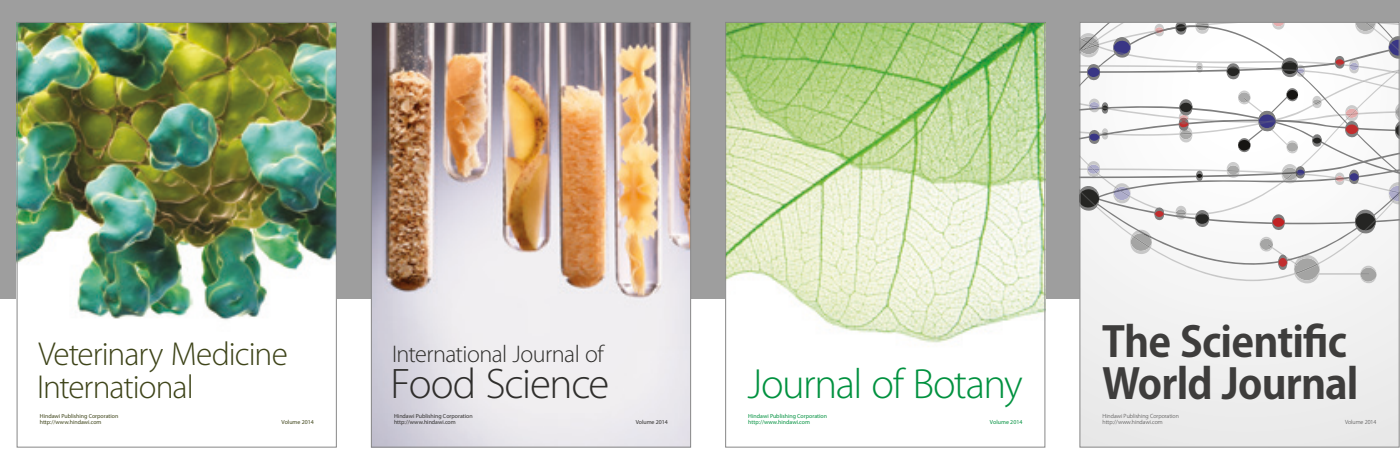

The Scientific

\section{World Journal}

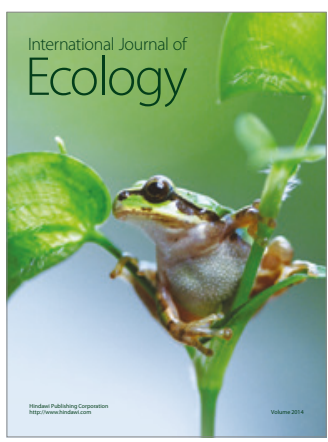

\section{Hindawi}

Submit your manuscripts at

https://www.hindawi.com
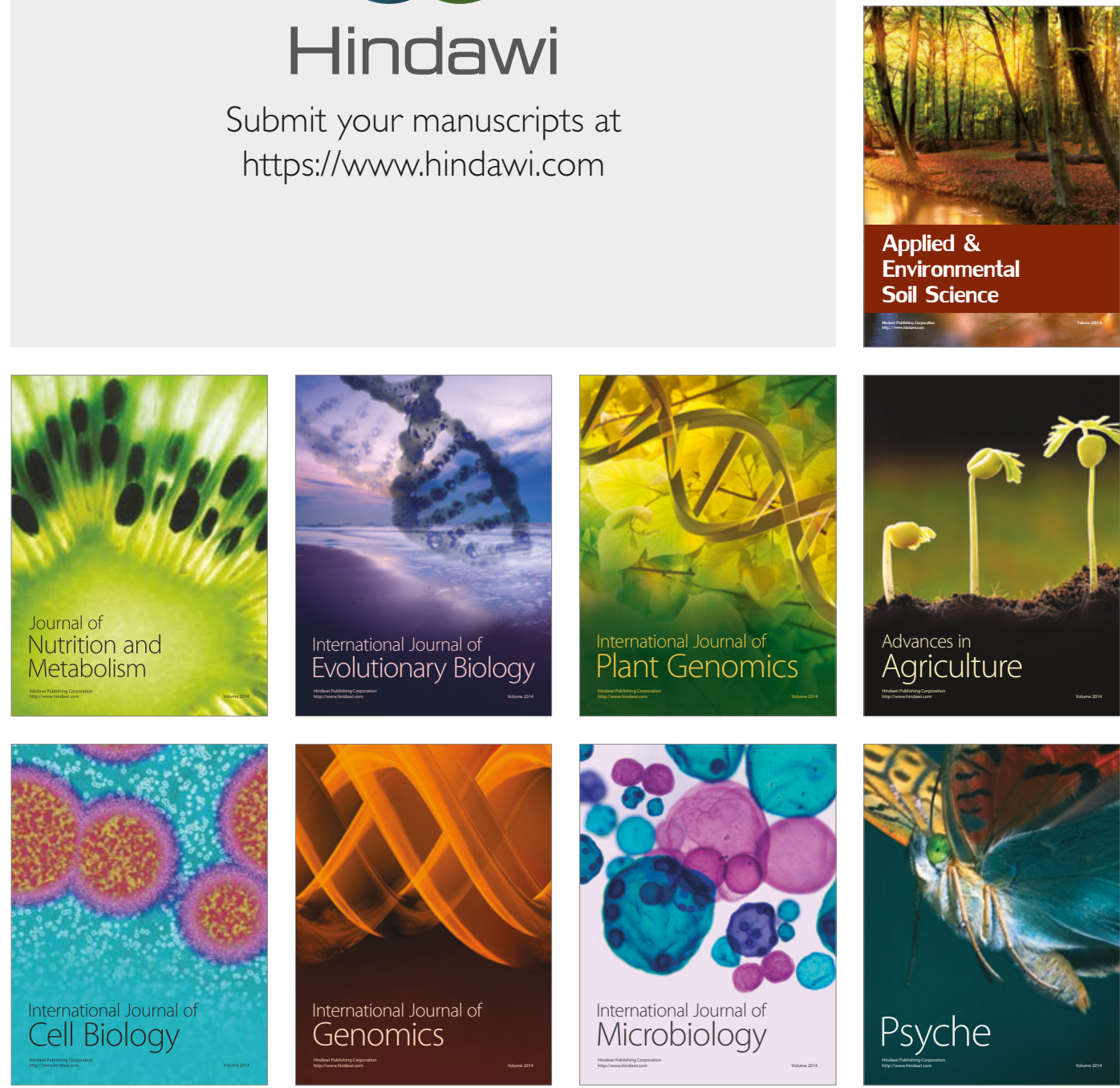

hternational Journal of Microbiology
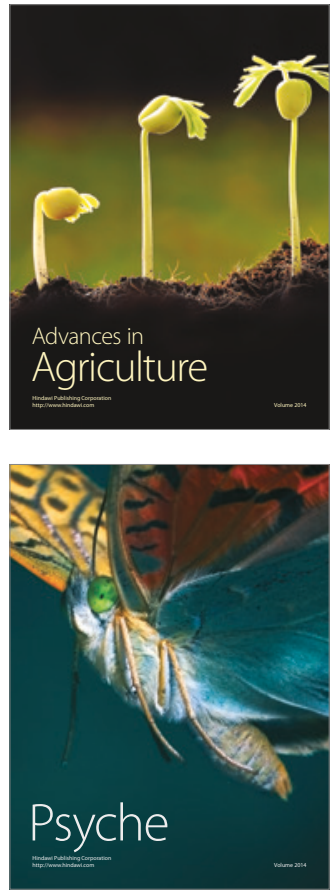